\title{
Analysis and critical review of ICH Q8, Q9 and Q10 from a generic pharmaceutical industry view point
}

\author{
Ljuba Karanakov $^{1 *}$, Jasmina Tonic-Ribarska ${ }^{2}$, Marija Glavas-Dodov ${ }^{3}$, \\ Suzana Trajkovic-Jolevska² \\ ${ }^{1}$ Replek Farm Ltd, Kozle 188, Skopje, Macedonia \\ ${ }^{2}$ Institute of Applied Chemistry and Pharmaceutical Analysis, Faculty of Pharmacy, Ss Cyril and Methodius University, \\ Vodnjanska 17, Skopje, Macedonia \\ ${ }^{3}$ Institute of Pharmaceutical Technology, Faculty of Pharmacy, Ss Cyril and Methodius University,Vodnjanska 17, Skopje, \\ Macedonia
}

Received: December 2011; Accepted: January 2012

\begin{abstract}
Generic industry aims to produce safe, efficient, built-in quality medicines that will satisfy patients' requirements and will be competitive on the market. In this paper, assessment of the need for quality by design (QbD) and process analytical technology (PAT) implementation by generic industry was made, by analysis of the ICH Q8, Q9 and Q10 guidelines and their implementation in European regulation. The review of the guidelines indicates differences in the life cycle of a generic medicine, leading to a final conclusion in terms of generic industry.

PAT provides statistical analysis and real time quality monitoring, as the basis for proactive quality management. Using QbD/PAT, quality is proved and improved throughout the entire life cycle.

Better understanding of the product and processes within a defined design space leads to easier proof of built-in quality throughout the life cycle of the medicine, faster and easier regulatory evaluation, faster time to market, as well as post marketing savings regarding costs and time.

Implementation of QbD/PAT as a systematic approach together with risk assessment as part of quality management system is a useful challenge to the generic industry and gives an opportunity for technological, temporal, financial and quality improvement.

It was concluded that having in mind its' own manufacturing capabilities the applicant should optimize the implementation of QbD in accordance with current good manufacturing practice guidelines. Implementation of QbD/PAT is an innovative challenge for the generic industry. Managing pharmaceutical quality system allows the top management to make right decisions at the right time.
\end{abstract}

Key words: $\quad$ ICH Guidelines, Pharmaceutical development, Quality Risk Management, Pharmaceutical Quality System, Quality by Design, Process Analytical Technology

\section{Introduction}

Satisfying the expectations of its' final users - the patients by obtaining safe, efficient, easily available, high quality affordable medicines is a major goal of the generic pharmaceutical industry.

This paper presents an overview of the ICH Q8, Q9,

\footnotetext{
* bubigos@yahoo.com
}

Q10 guidelines for generic medicines for human use.

The goal is to recognize the benefits, challenges and opportunities deriving from implementation of the guidelines, including Quality by design $(\mathrm{QbD})$ and Process analytical technology (PAT), from a critical viewpoint of the generic pharmaceutical industry related to the regulation and authorities evaluation of the application, concerning medicine quality.

Description and analyses of the ICH Q8, Q9, and Q10 focused on determination of QbD and PAT, as well 
as European quality regulations and guidelines, will point out the contrast of the generic medicine life cycle, considering their implementation, concluded from aspect of the generic industry.

\section{ICH Q8, Q9, Q10}

Implemented as scientific guideline in European regulation (Volume 3), ICH Q8 - Pharmaceutical development gives guidance for: optimization of medicine quality through its life cycle, presentation of science based data in CTD Module 3 and meaning of transfer from finished product inspection to build in quality and real time release testing. This guideline gives possibility and guidance for development studies where risk management, as part of efficient pharmaceutical quality system, is implemented. The guidelines ICH Q9 Quality Risk Management and ICH Q10 Pharmaceutical Quality System, differing from Q8, are not defining the content of the CTD Module 3. They only provide guidance, for basic, expectations for presentation of the development and certification of the medicine quality. Adopted ICH Q9 and ICH Q10 are implemented as sections of PART III of European Union Good Manufacturing Practice (EMA, 2011). The aim of PART III is to explain the regulatory expectations and should be considered as source of information for current best practice (ECA, 2011).

\section{QbD/ PAT Implementation}

The empirical approach is based on predefined specification that available data should comply with. Determination of one variable at a time may end up with Out of Specification results, leading to quarantine or withdrawal of the product. Controls of materials and processes are repeated after each cycle, production process is fixed, without possibility of unauthorized changes, and its validation is based on minimum three pilot batches manufactured at industrial facilities. The control strategy is out of site testing and inspection, focused on repeatability and optimization of processes, controlled in terms of specification approved with the Marketing Authorization (MA). Retrospective quality assurance and corrective measures, based on in-process and finished product analysis are used, where opportunities for statistical and basic problem cause analysis are limited (ICH Q8, 2008).

Differing from the empirical approach, QbD/PAT implementation represents a systematic-multidimensional determination of Critucal Quality Atributes (CQAs) within design space. Design space is defined depending on Quality Target Product Profile (QTPP) and available resources, using prior scientific knowledge, risk assessment and design of multivariable experiments, to better understand the qualitative attributes of input materials and processes. Product quality is reflected in the approved design space. Data on safety and efficacy in this phase are obtained by performing in vitro studies and in vitro/in vivo correlations (EMA Inspection Assessment, 2007). Specification in accordance with regulatory requirements and risk assessment of CQA, for materials and product quality, results in determination of CQAs of the performance for testing and PAT tools should be used. Production processes are flexible and scale up of manufacturing to industrial facilitates is easier and faster. QbD product almost never fails the bioequivalence study and transfer - scale up to commercial manufacturing is predictable. Ongoing quality management leads to processes validation through the life cycle of the medicine. Control strategy is based on scientific knowledge and risk assessment. PAT enables statistical analysis and quality monitoring at real time, as a base for proactive quality management (EMA Reflection paper, 2006). Using QbD/ PAT, the quality performances are improved through the entire life cycle.

Selection of components, formulation, manufacturing process and control strategy development for easier and faster commercialization of a product with a consistent quality is at major focus of the generic industry. There are no strict requirements for $\mathrm{QbD} / \mathrm{PAT}$ application. Depending on his needs and possibilities of proving built in quality, the applicant should optimize QbD implementation in compliance with the Current Good Manufacturing Practice (cGMP) guidelines. Implementation of QbD/PAT is innovative challenge for the generic industry with opportunities for robust processes, cost reduction, lowered rate of batch failures and faster science based regulatory assessment (Varu, 2010). QbD enables real time release improvement of the product and proceses after marketing within the approved design space with no need to apply for post marketing variations (ICH Q8, 2008). This leads to reduced postmarketing costs. Variations may apper during the development as well. For example variable dissolution rate at the end of the development will prolonge the time to market. Investing in DoE at the beginning of development helps to realze where the variations can come from and this will shorten the time to market (Snee, 2008). Implementation of $\mathrm{QbD} / \mathrm{PAT}$ gives an opportunity for predictable final outcome, easier and faster transfer of manufacturing proces from development to industrial capacities wich leads to faster time to market (IMB, 2005). Managing quality pharmaceutical system enables the top management to bring right decisions at right time.

\section{Generic industry critical point of view for imple- mentation of ICH Q8, Q9, Q10 guidelines and PAT}

The guidelines ICH Q8, Q9 и Q10 are complementary to each other. ICH Q8 is tightly connected with ICH Q9. Quality Risk Management (QRM) is based on the experiments performed during the pharmaceutical development. Risk assessment enables designing a high quality product during implementation of $\mathrm{QbD}$, definition of the 
CQAs and quality specification. Risk assessment helps to determine a suitable and acceptable design space. ICH Q8 refers to better understanding of product and process attributes, based on accumulated knowledge and risk assessment, due to constant improvement of product quality. On the other hand ICH Q10 gives guidance for implementation and management of modern quality system. While it doesn't talk for a specific product but for the system as a whole, however, the focus is on specific measurements of product and processes quality that demonstrate continuous improvement of the realized product, that should satisfy consumers' quality requirements. ICH Q10 provides management of changes within the design space. Any successfully designed pharmaceutical quality system contains elements of risk management (ICH Q9, 2005). From this it can be concluded that to enjoy the benefits of implementing ICH Q8 and ICH Q9 implementation of ICH Q10 cannot be avoided. For successful implementation of QbD and PAT, the industry should follow the directions given in the guidelines ICH Q8, Q9, Q10.

Because of the rigorous requirements set for the manufacturing processes, the pharmaceutical industry is far behind other industries in terms of improving the techniques and processes for on line control. On the other hand, regulators require following of new technology achievements, and the PAT represents a chance for the pharmaceutical industry to bring innovation in the development and control of manufacturing processes.

PAT is the basis for successful implementation of ICH Q8, Q9 and Q10 in the development of a medicine whether it is innovative or generic. Implementation of ICH Q8, Q9, Q10 and PAT will allow distribution of products with proven quality, safety and efficiency to end users - patients. Modern approach to development through improvement of technology brings a lot of benefits.

Production time, number of defective products, life cycle of improved quality medicine, documentation, manufacturing costs and manual error are reduced. Manufacturing capacities, use of high technology and safety of the operator are increased. This approach enables marketing the product under the principle of real time release, use of state-ofthe-art technologies and guaranteed quality level (unit to unit) in production (Varu, 2010). Establishment of continuous processing and improvement of the effectiveness and management of variables, gives an opportunity for more pragmatic approach of medicines agencies and continuous improvement during evaluation, which will enable the manufacturer to be more competitive on the market.

For all this to be achieved manufacturers and the competent authorities will have to exert a lot of effort. Reciprocal communication will have to rise to a higher level and all issues that will arise will need to be considered interactive.

Besides the chance for quality improvement, safety and efficacy of the product and processes, the challenge for the industry to transit from traditional to more modern and improved access to development, without costs increase, must be taken into account. But this challenge without the investment is almost impossible.

Successful implementation of the new paradigm for most of the generic manufacturers will represent a change of the company policy, and even change of the organizational structure. The guidelines are accepted by European Medicines Agency (EMA) but they are not mandatory, except for elements prescribed in other guides such as: $\mathrm{ICH}$ M4 (R1), International organization for standardization (ISO), cGMP national guidelines. It's up to the manufacturer to decide which elements in what extent should be implemented. Whether for a generic industry is worthwhile to introduce new elements and principles to existing products or only to new products a good analysis should be done. Introduction of the new approach to existing products will entail reporting variations among authorities, and therefore additional costs.

\section{Deciding upon QbD/PAT implementation}

Since the implementation of the new improved approach is at an early stage, there is still no accurate data on the possible cost benefit. However, based on the available data on manufacturing costs of a generic medicine assumption can be made.

Development of medicine using a traditional approach takes approximately 4.5 million dollars. If costs are shown for each stage of the process separately, an assumption can be made in which phase of the process the costs will be increased or reduced and what the implementation of a modern approach would mean for a generic industry. Table 1 refers to the development costs of generic prescription medicine in Canada (Canadian generics, 2010)

Table 1. Structure of costs for development of a generic medicine using traditional approach, given by stages expressed in dollars

\begin{tabular}{cc}
\hline \hline $\begin{array}{c}\text { Generic medicine } \\
\text { development stages }\end{array}$ & $\begin{array}{c}\text { Structure of costs } \\
\text { expressed in dollars }(\$)\end{array}$ \\
\hline API providing & 250000 \\
Formulation & 250000 \\
Testing, manufacturing process, \\
scale - up, manufacturing \\
Bioequivalence \\
$\begin{array}{c}\text { Regulatory affairs until and } \\
\text { after granting of the marketing } \\
\text { authorization }\end{array}$ & 1000000 \\
\hline
\end{tabular}

From the foregoing data on the benefits of the implementation of QbD/PAT an assumption can be made that the costs associated with regulatory activities would be re- 
duced by $10-15 \%$, the cost of transfer from laboratory to industrial production would be reduced by $10-20 \%$ and the cost of providing active substance would be reduced by $4 \%$, but the initial costs for formulation will need to be increased. After the time for return on investment, the costs for this part of the process should be reduced as well.

In what extent the costs for research and formulation development will increase depends on the manufacturer's decision, to what extent, how and weather, to improve its performance by introducing innovation.

Taking into account the structure of manufacturing costs of a generic medicine, that the generic industry should implement ICH Q8, Q9, Q10 and PAT can be concluded.

The generic industry doesn't have any costs for development of new molecules and therefore selling price of a generic medicine is much lower than the selling price of the innovative medicine, and profit margins are higher than for innovative companies (Malhotra, 2010).

Also selling price of the generic medicine is many times higher than the costs of active substance and formulation that gives the opportunity for generic manufacturers to invest in the implementation of $\mathrm{QbD} / \mathrm{PAT}$ and again to be profitable (Malhotra, 2010).

To support the concept, simpler and faster access to quality safety and efficacy medicines for all, generic manufacturers should be reviewed, at what level of the road to success is and where he wants to be, and depending on the above he will decide whether the new paradigm is the way to success.

If the manufacturer makes a positive conclusion, the whole process of implementation should be accepted as an investment, which depending on the extent will sooner or later return, and products processes will be constantly improved.

If the generic manufacturer decides to begin the innovation by implementing the ICH Q8, Q9, Q10 and PAT, consultations with the competent authorities, for almost every part of the process, will be necessary.

For positive decision of a generic company on implementation of the new paradigm QbD/PAT, primarily the top management has to realize that the implementation is necessary and it's a useful challenge and opportunity for the company.

Need of management awareness is clearly shown by Woelbeling and co-workers (Woelbeling et al., 2008). Assessment by interviews of 11 PAT case studies, where PAT projects were executed was performed. The following categories have been defined and considered for this assessment: quality, process, risk, cost, personnel, tools, time validation, organization, regulatory. It was concluded that when PAT is professionally implemented the quality, risk validation and regulatory aspects can be summarized as a positive experience. Even the companies with less experience in PAT implementation have positive expectations. PAT enables increasement of process understanding and the utilization of different technologies accompanied with management of a lot more data which improves the communication between departments, as well as advanced and comprehensive data analysis and assessment. Considering cost benefits it's still early for precise calculations, but experience shows decreased indirect costs. Benefits are claimed in terms of higher yields, reduced cycle times and fewer rejections/reworks rather than in terms of fewer personnel.

Once management has accepted the need for implementation of QbD/PAT, the next step is to decide whether the implementation will be conducted for existing or new products planned, keeping in mind that changes will need to reported as variations to the authorities. Whatever has been decided, a plan and framework for implementation should be made. The framework will present the entire life cycle of the generic medicine, and define in which phase of the life cycle, and in what extent should be undertaken for successful implementation of the new paradigm. Structuring of the data allows assessment of resources, technologies, personnel and time for development, which in turn is a major challenge for the generic manufacturer for faster placing on market of high quality product.

\section{Framework for QbD/PAT implementation}

Proposed framework for the implementation of $\mathrm{QbD} /$ PAT is given in the study of Chatterjee (Chatterjee, 2010). The framework consist of five phases concerning the core principles of $\mathrm{QbD}$ defined as product and process design and understanding, process predictability and process performance.

Phase 1 addresses the first steps in generic development such as product selection and Site Capability Analysis. This is an opportunity for the manufacturer to realize its' capabilities and recognize the increased basic costs and potential standard costs of pursuing a new product.

In this phase a Product Design Specification summarizing the product's key attributes, risk analysis from a clinical perspective for the process predictability and validation, and project timeline should be developed as criteria for project performance. As regulatory required some design elements, such as dosage form, strength, route of administration, identity, assay and content uniformity are expected to be constant during development.

The second phase describes the elements of development and characterization. For better process understanding, a platform approach should be adopted for one type of product development, at a time (Chatterjee, 2010). The formulation knowledge gained from key excipient, binder and other functional excipient elements can be used for all development activity. In vitro/in vivo correlation if provided by the innovator and risk analysis from phase 1 will steer the product design and characterization. For better understanding of the component variability active pharmaceutical ingredient (API) as well as excipients should be well characterized and presented in the development dossier. 
Measurement Sensitivity Analysis (MSA) should be used on all in-process and release tests used to steer and measure the process stability and product performance. This will ensure that the measurement tools being used to evaluate the process have the resolution to tell good from bad.

Phase 3 addresses the: location, selection, process design and technology transfer. Technology transfer depends on the level of process understanding during the development. A risk analysis before process design and MSA after the method transfer should be repeated. These elements enable simple process design with maximum possibility for success.

The fourth phase considers the data showing in the application submitted for MA. Characterized process and product performance, batch record and control strategy within a robust design space should be shown in MA documentation.
Phase 5 shows that the measurement of true critical process parameters at the right point of the process, defined during structured development and process design gives an opportunity for real time intervention if needed. Compliance measurements and use of corrective and preventive actions, generated by each product can be used as a driver for continuous improvement of the business performance.

Knowledge management and knowledge gained from the past product as structured routine evaluation is beneficiary for the developing product and processes and will limit the risk profile. Decisions and choices for the developing product will be simplified.

Following a structured framework with clearly defined metrics at each stage gate will reduce any confusion and variability in the product development process and will facilitate a faster time to market. The structured approach al-

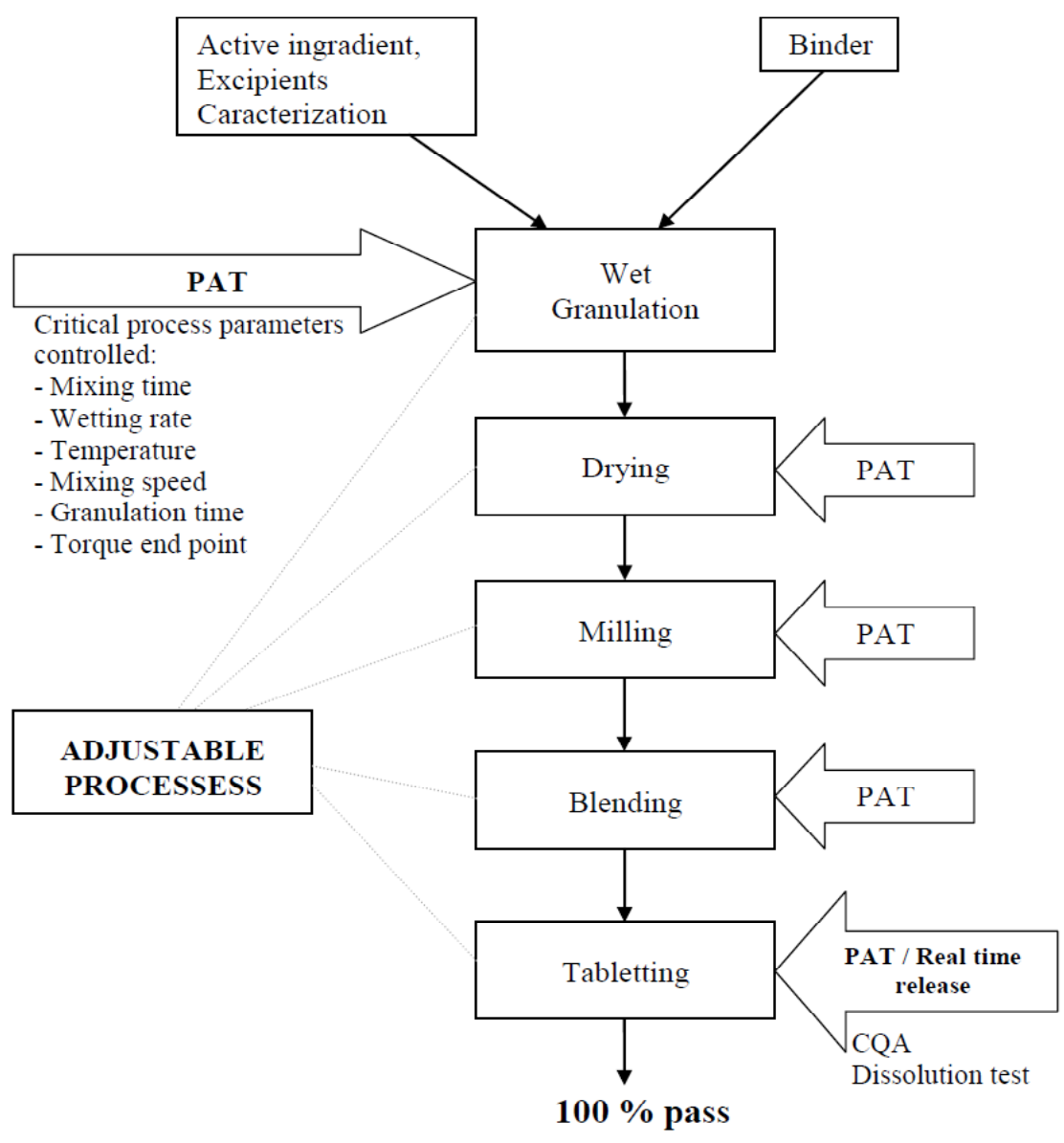

Critical Quality attributes assessed:

- Granule properties

- Tablet properties

Fig. 1. Monitoring of tabletting process and proces control using wet granulation method when QbD/PAT is implemented. 


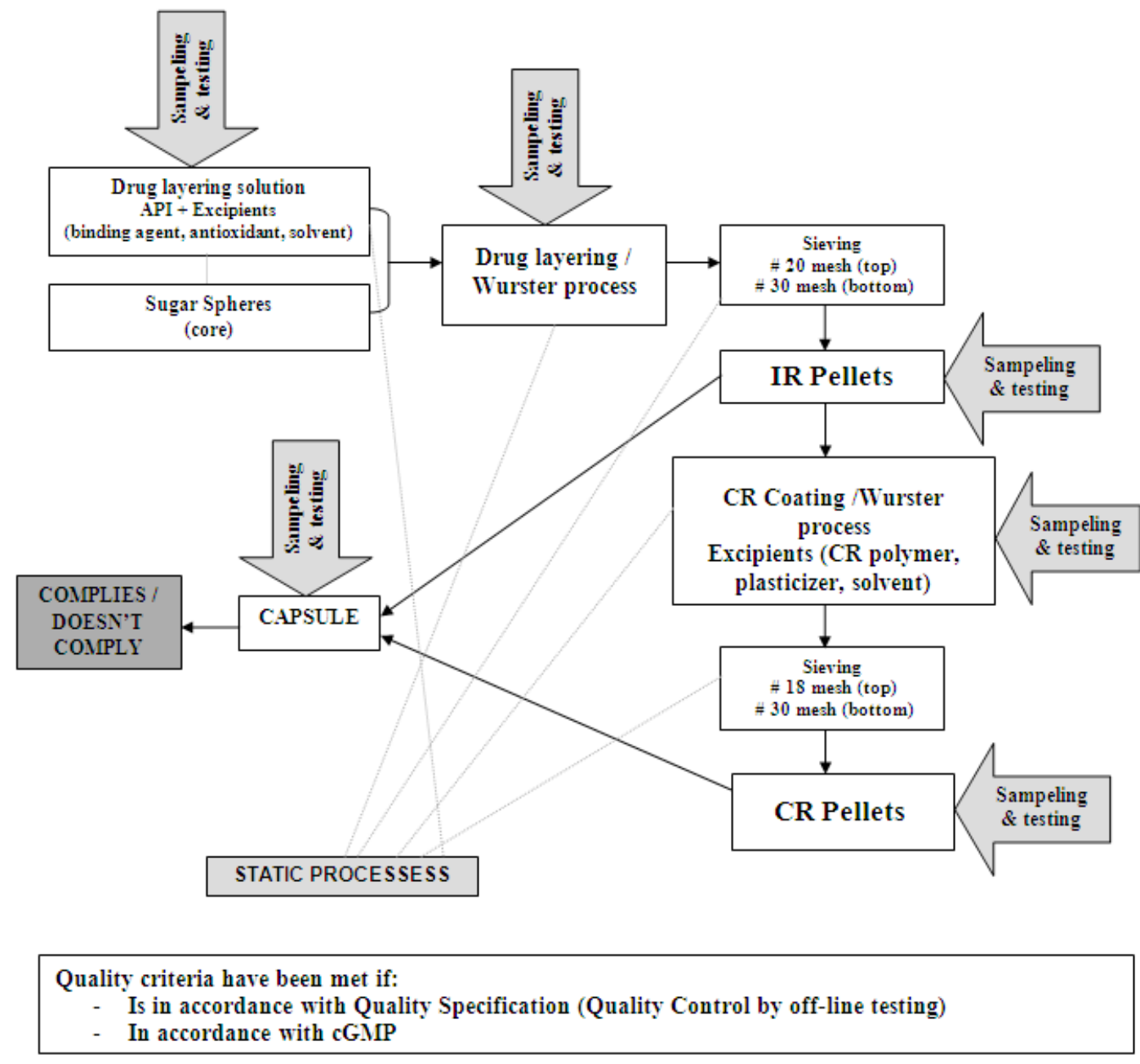

Fig. 2. Monitoring of the manufacturing process and process control of modified release capsule (pellets filled with an immediate release and controlled release pellets) without implementation of QbD/PAT

lows the organization to measure and focus its continuous improvement activities upon those elements that have the largest potential to increase and sustain business performance (Chatterjee, 2010).

For better understanding of the importance for development of process controls in comparison with testing by one parameter, examples for monitoring of manufacturing processes are presented in Figs. 1, 2 and 3.

Fig. 1 shows typical tabletting process where wet granulation method is used, when QbD/PAT is implemented. API and excipients are characterized. CQA defined in design space are measured by PAT. During wet granulation CQA such as mixing time, wetting rate, temperature, mixing speed, granulation time and torque end point were determined for assessment of granule properties. Tablet properties were assessed by performing suitable dissolution test. When $\mathrm{QbD} / \mathrm{PAT}$ is implemented final product is real time released and $100 \%$ in compliance with product quality specification.
Fig. 2 is showing a manufacturing process of modified release multiple-unit dosage form, capsules containing imediate release (IR) and controlled release (CR) pellets, and its control without the implementation of QbD/PAT. Finished product is in compliance with quality criteria if it meets the requirements from quality specification, and quality control is performed at another location, testing one parameter at the time. Processes and testing are performed in accordance with cGMP, but (i) API and excipients have not been characterized; instead of that they are sampled and tested if they comply with a predefined specification; (ii) intermediate processes in the manufacturing of modified release capsules, such as preparation of API layering solution, coating of sugar spheres (cores) with a layer of API using Wurster fluid-bed process, sieving, preparation of the polymeric coating suspension, CR coating of pellets and re-sieving are fixed. Therefore, they are without ability to monitor and determine parameters such as API content in the layering solution, content and content uniformity and size of IR pellets, polymeric coating suspension vis- 


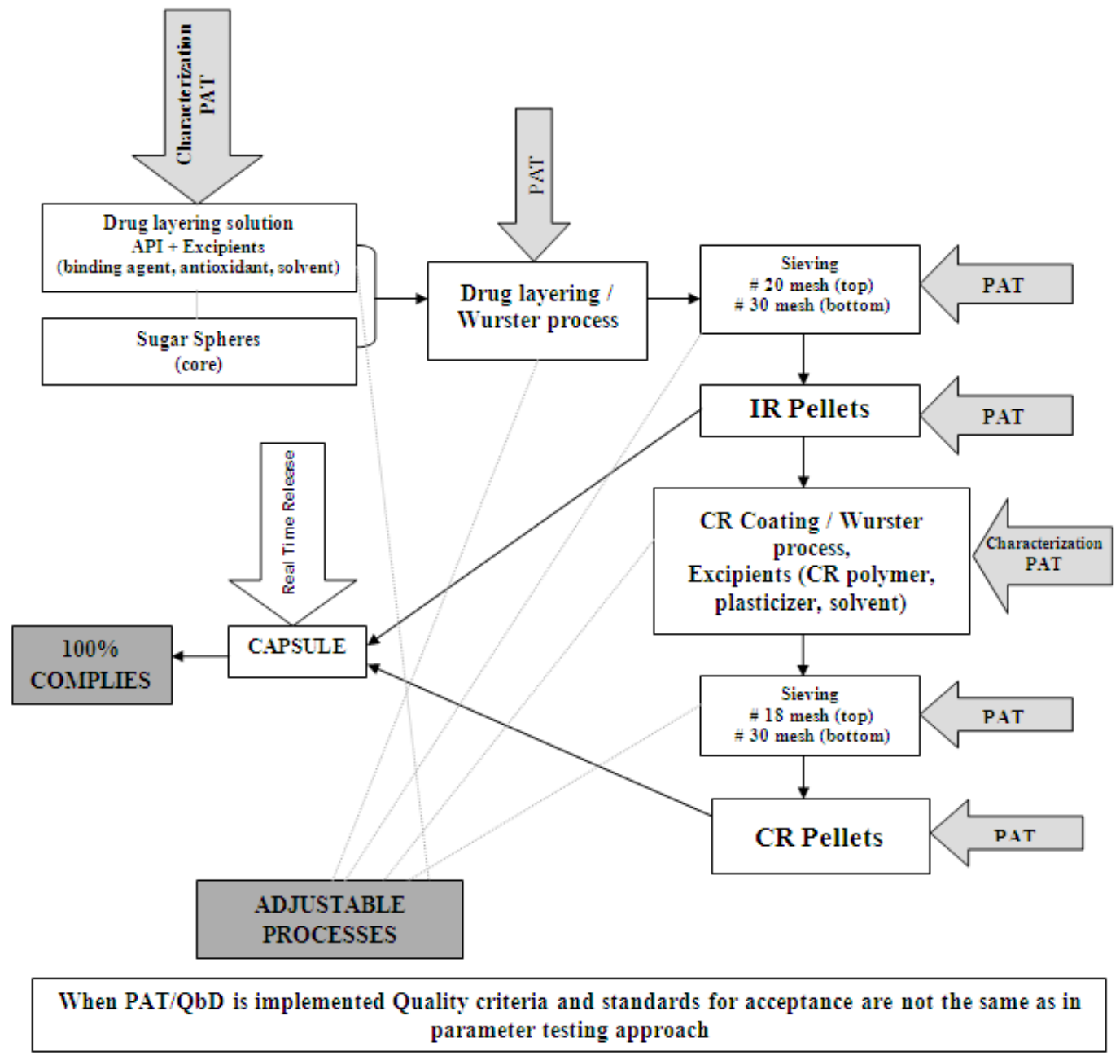

Fig. 3. Monitoring of the manufacturing process and process control of modified release capsule (pellets filled with an immediate release and controlled release pellets) with implementation of QbD/PAT

cosity, the thickness of CR membrane, the size of CR pellets and drug release from CR pellets. Instead of that, the control of API layering solution, IR pellets, suspension for $\mathrm{CR}$ coating and $\mathrm{CR}$ pellets are at the end of the processes, by sampling and testing. Filled capsules are also sampled and tested due to quality control. The final outcome may be a finished product that meets specification requirements, or does not, leading to product failure, retrospective analysis of the cause of the malfunction and the time and costs for placing the medicine on the market are increased.

Unlike the traditional approach, implementation of QbD/PAT offers a lot of possibilities, as shown in Fig. 3. When $\mathrm{QbD} / \mathrm{PAT}$ is implemented product is in compliance with quality criteria if it meets the specification, but measurements of critical process parameters are performed during processes and not after finishing. Process and testing are carried out in accordance with cGMP as well, but (i) API and excipients are characterized which allows defining optimal solubility of the API and stability of the API layering solution and maximal achievement of content uni- formity; (ii) intermediate processes are flexible and critical parameters are controlled during process. Real time testing is performed during pellets production. The final outcome is a finished product that meets specification requirements and the time and costs for placing the medicine on the market are decreased.

Competent authorities are also concerned by the implementation of the new paradigm and will have to change the system of evaluation and inspection. The evaluation should be based on science and risk assessment. Specialists in all areas of evaluation will need to be recruiting and continuously trained. Presentation of data from the traditional and new approach in the documentation is different, therefore the competent authorities should be more flexible, and over time setting of more specific directions may be needed. Decisions regarding the design space and its' extent should be made without infringement of the confirmed medicine quality. In the future assessment of the need for variations submission should be devised and even need for change of medicines control and system reorganization may appear. 
Inspectors should be thoroughly trained in terms of risk management tools and principles in order to perform proper inspection, companies' pharmaceutical quality systems.

Alignment of industry and competent authorities will be very long and difficult journey, but the goal can only be achieved by mutual cooperation and understanding.

\section{Conclusion}

Investment in the development studies, as a source of scientific knowledge or knowledge gained from previous experience, enables the applicant to establish a wider design space and better understand the product and processes. This leads to easier improvement of the built in quality through the life cycle of the medicine, faster and easier regulatory assessment, as well as savings on post approval costs and time. Due to economic competition, wider design space leads to faster commercialization and reduced postapproval variations.

Implementation of QbD/PAT as a systemic approach using risk assessment, as a part of the Quality management system, is beneficial, challenging and offers the generic industry opportunities for technological, time consuming, financial and quality improvements.

Any way it's up to generic industry to decide for the way and extent of QbD implementation. But any industry for own improvement should be lead be Nelsons' saying "You cannot do today's job with yesterdays method and be in business tomorrow" (Horatio Nelson Jackson).

\section{References}

Ahlert, J., 2007. ICH Q8: Pharmaceutical Development. Regulatory Requirements Directed by the New Note for Guidance (EMEA/CHMP/167068/2004) in Comparison to the Previous Guideline (CPMP/QWP/155/96). A Critical View from the Generic Pharmaceutical Industry. M. A. Rheinischen Friedrich-Wilhelms-Universität Bonn

Chatterjee, B., 2010. A QbD Implementation Roadmap for the Generics Industry. 16 July, Available at: http://www.pharmaqbd. com/qbd_roadmap_generics/ (accessed 3 May 2011)

European Compliance Academy, GMP news: http://www.gmpcompliance.org

European Compliance Academy, 2011. GMP news. EU-GMP Guide: New Introduction with Clarification of Status of Part III. 24 February [online] Available at: http://www.gmpcompliance.org/

European Compliance Academy, 2010. GMP news. "Outsourced Activities" - Revision of Chapter 7 of the EU GMP Guide. 17 November [online] Available at: http://www.gmpcompliance.org/

European Compliance Academy, 2010. GMP news. European Commission issues new Draft of Chapter 5 "Production" of the EU GMP Guide. 25 November [online] Available at: http://www.gmp-compliance.org/

European Compliance Academy, 2011. GMP news. The New GMP Annex 11 and Chapter 4 is Europe's Answer to Part 11. 27 January [online] Available at: http://www.gmpcompliance.org/
European Compliance Academy, 2011. GMP news. New EU GMP Guide Chapter 4 on Documentation. 19 January [online] Available at: http://www.gmp-compliance.org/

European Compliance Academy, 2011. GMP news. EMA publishes ICH Q9 and ICH Q 10 as Part 3 of the EU GMP Guide. 10 February [online] Available at: http:/www.gmpcompliance.org/

European Compliance Academy, 2010. GMP news. Revision of Chapter 6 of the EU GMP Guide Quality Control - New Concept Paper. 15 December [online] Available at: http:// www.gmp-compliance.org/

European Compliance Academy, 2010. GMP news. EMA revises its Process Validation Guidelines. 29 April [online] Available at: http://www.gmp-compliance.org/

European Medicines Agency, 1995 - 2011. http://www.ema. europa.eu (Last date of access 03.2011)

European Medicines Agency, 1995 - 2011. http://ec.europa.eu/ health/documents/eudralex/index en.htm

European Medicines Agency, 1995 - 2011. http://www.emea. europa.eu/Inspections/PAThome.html

European Medicines Agency Inspections, Assessment, 2006/450653/EMEA/CHMP/CVMP/QWP,10 July 2007 on the quality of medicinal products containing existing/ known active substances

European Medicines Agency, Note for Guidance, June 2009/265145/ EMEA/CHMP/ICH on Pharmaceutical Development ICH Topic Q8, Q9 and Q10, Quality Risk Management, Pharmaceutical Quality System, Questions and Answers

European Medicines Agency, ICH guideline, 2009/265145/ EMEA/CHMP/ICH, December 2010 on Q8, Q9 and Q10, Questions and Answers

European Medicines Agency, Note for Guidance 2004/167068/ EMEA/CHMP/ICH, 14 November 2005 on pharmaceutical development ICH Q8, Pharmaceutical Development

European Medicines Agency, Note for Guidance 2004/167068/ EMEA/CHMP/ICH, June2009 on pharmaceutical development ICH Topic Q 8 (R2), Pharmaceutical Development

European Medicines Agency, EudraLex, Guidance, Vol 4 1064597/SANCO/C8/AM/sl/ares, 2010 Introduction to Good Manufacturing Practice Medicinal Products for Human and Veterinary Use

European Medicines Agency, EudraLex, Guidance, Vol 4 3374/ ENTR/F/2/AM/an D, 2010 Part II: Basic Requirements for Active Substances used as Starting Materials

European Medicines Agency, EudraLex, Guidance, Vol 4 Chapter 7 on Contract Manufacture and Analysis

European Medicines Agency, Reflection Paper 2005/277260/ EMEA/INS, March 2006 on Chemical, pharmaceutical and biological information to be included in dossiers when Process Analytical Technology (PAT) is employed.

Food and Drug Administration, Guidance for Industry PAT A Framework for Innovative Pharmaceutical Development, Manufacturing, and Quality Assurance, 2004.

Food and drug administration. Example Quality Overall Summery. Available at: http://www.fda.gov/downloads/ Drugs/ Development Approval Process / How Drugs are Developed and Approved / Approval Applications / Abbreviated New Drug Application AND A Generics / ucm120977.pdf (Accessed 10 July 2011).

Canadian generics, 2010. Generic prescription drug development; Generic manufacturers invest three to six years and an 
estimated \$ 4 million to bring a new generic drug to market. February Available at: http://www.canadiangenerics.ca/en/ resources/docs/GenericDrugDevelopment.pdf

IBM Business Consulting Services, 2005. The metamorphosis of manufacturing from art to science. [online] Available at: http://www935.ibm.com/services/us/imc/pdf/ge510-4034metamorphosis-of-manufacturing.pdf [7 February 2011].

$\mathrm{ICH}$ harmonization for better health, http://www.ich.org/home. html (Last date of access 03.2011)

International Conference on Harmonisation, Guideline ICH Q8 (R1) - Pharmaceutical Development, Step 4, November 2008

International Conference on Harmonisation, Guideline ICH Q10 - Pharmaceutical Quality System, 2008

International Conference on Harmonisation, Guideline ICH Q9 Quality Risk Management. 2005

International Conference on Harmonisation, Guidance for Industry Q8, Q9, and Q10 Questions and Answers, 2010

International Conference on Harmonisation, ICH Harmonised Tripartite Guideline - Test Procedures and Acceptance Criteria for New Drugs Substances and New Drug Products: Chemical Substances - Q6A, 1999

International Conference on Harmonisation, Quality Implementation Working Group on Q8, Q9 and Q10 Questions \& Answers, 2009

Jolley J., 2008. EIPG General Assembly, Industry Implications of Pharmaceutical Quality ICH Guidelines.

Lionberger, R.A., 2008. FDA Critical Path Initiatives: Opportunities for Generic Drug Development. American Association of Pharmaceutical Scientists, [Online] 10 (1), pp. 103 - 109 Available at: http://www.springerlink.com/ (Accessed 19 July 2010)

Malhotra, G., 2010. Pharmaceutical Costs, Technology Innovation, Opportunities \& Reality. [online] Available at: http://www. pharmpro.com/articles/2010/03/business-PharmaceuticalCosts-Technology-Innovation-Opportunities-and-Reality/ [5 February 2011]

Nasr, M.M., 2010. Corona conference on QbD/PAT. Regulatory Aspects of Pharmaceutical Development and Manufacturing in the 21st Century - FDA Perspective. [conference] 20 September. Corona, Italy

Rick, N.G., 2009. Drugs From Discovery to Approval. 2nd Edition, New Jersey: John Wiley \& Sons Inc.

Robert, J-L., 2010. ICH-GCG ASEAN: Introduction to ICH. [workshop] 26-28 July, Kuala Lumpur, available at: http://www.ich.org/trainings/ich-trainings/ich-q8q9q10guidelines.html (Accessed 03,2011)

Robert, J-L., 2010. ICH-GCG ASEAN: Q8(R2): Pharmaceutical development. [workshop] 26-28 July, Kuala Lumpur, available at: http://www.ich.org/fileadmin/Public_Web_ Site/Training/ICH_Endorsed_Training_Events/ASEAN_ training_on_Q8_Q9_Q10_Guidelines/Q8_Pharma_ development_JL.Robert.pdf (Āccessed 03, 2011)

Varu, R.K., Khanna A., 2010. Opportunities and Challenges to Implementing Quality by Design Approach in Generic Drug Development. Journal of Generic Medicines, 7, (1), pp. 60-73

Woelbeling, C., 2008. Creating Quality by Design/Process Analytical Technology (QbD/PAT) Management Awareness. Pharmaceutical Engeineering, 28, (3)

Ward, M., 2005. IV Pan American Conference on drug Regulatory Harmonization: ICH Update: Developments and Future Directions.[conference] 2-4 March, Boca Chica, Dominican
Republic, available at: www.paho.org

Yu, L.X., 2008. Pharmaceutical Quality by Design: Product and Process Development, Understanding, and Control. Pharmaceutical Research, 25, (4), pp. 781- 791 Available at: www.springerlink.com (Accessed 13 February 2010)

Yu, L.X., Lionberger, R., Olson, M. C., Johnston, G., Buehler, G., Winkle, H., 2009. Quality by Design for Generic Drugs. Pharmaceutical Technology, 33, (10), pp. 122-127 Available at: http://pharmtech.findpharma.com/pharmtech/Article/ Quality-by-Design-for-Generic-Drugs/ArticleStandard/ Article/detail/631723 (Accessed 19 July 2010)

\section{Web references}

Babu, K.S., 2007. Introduction to ICH Q8 \& Q9 guidelines. 29 November. Watson Pharma, India

Baum, R., 2008. Public ICH Meeting. Q8 (R1) - Annex to Q8 Pharmaceutical Development. 14 November. Brussels, Belgium

Blackwell, J., 2009. BioProcess International Conference. For QbD, What Should a Small Company Do and Why? 12-16 October. Rleigh, NY

Cerulean Associates LLC, 2007. Is Quality by Design Right for My Organization...? OR Would IPreferQuality by Crisis? [online] Available at: http://www.ceruleanllc.com/wpcontent/articles/ eWorkbook_IsQbDRightforMyOrganizationCERULEAN. pdf [11 December 2010]

Commission Regulation 2008/1234 EC of 24 November 2008 concerning the examination of variations to the terms of marketing authorizations for medicinal products for human use and veterinary medicinal products

Coulson L., Robert J.L., Ertle L., 2009. EMEA/Efpia QbD Application Workshop, Continuous Quality Verification An Approach to Process Validation September 29, London

Cook, G. D., Venkateshwaran,G. T., Simmons, P.S. Quality by design. (World Pharmaceutical Frontiers) [online] Available at: www.worldpharmaceuticals.net [Accessed 11 December 2010]

Council Directive 2001/29/EC of 22 May 2001 on the harmonisation of certain aspects of copyright and related rights in the information society.

EFPIA (European Federation of Pharmaceutical Industries and Assosiations), 2006. Mock P2 for "Examplain" Hydrochloride. [online] Available at: http://www.efpia.org/ Content/Default.asp?PageID=450 [19 February 2011]

European Medicines Agency, EudraLex, Guidance, Vol 4 Chapter 2 on Personnel

Euro Pharma Today, 2009. EU Pharmaceutical Industry Starting to Incorporate More QbD - Like Elements in Applications. [online] Available at: http://www.europharmatoday. com/2009/12/eu-pharmaceutical-industry-starting-toincorporate-more-qbdlike-elements-in-applications.html [15 September 2010]

Express Pharma, 2010. Quality by design approach to cGMP. [online] Available at:http:/www.expresspharmaonline. com/20100930/pharmatechnologyreview01.shtml [11 December 2010]

Food and Drug Administration, http://www.fda.gov

Food and Drug Administration, Guidance for Industry: Quality System Approach to Pharmaceutical cGMP Regulations, US Department of Health and Human service Rockville, MD: FDA, 2006

France, G., Roenninger, S., Hamilton, S. ICH. Implementation of Q8, Q9 \& Q10. 
Ghani, S., 2007. WHO Training Workshop on Pharmaceutical Development with a Focus on Pediatric Medicines, Regulatory Aspects of Product Development ICH Process Q8, Q9, Q10 [workshop] October 15-19

Gibson, M. ed., 2004. Phatmaceytical Preformulation and Formulation - A Practical Guide from Candidate Drug Selection to Commercial Dosage Form. Boca Raton, FL, CRC Press

Griffith, E., 2004. Risk Management for the Pharmaceutical Industry. Available at: http://www.pharmpro.com/ Archives/2004/03/Risk-Management-Programs-for-thePharmaceutical-Industry/

Gough, H.P., ICH Q9 'Quality Risk Management' - an industry view

Health Canada, http://www.hc-sc.gc.ca

Ho, K. EMEA, SME Office. "Quality by Design” Application and Perspectives for biological

Holte, Ø., 2009. Norwegian Medicines Agency. A risk-based approach to pharmaceutical development ICH Q8/Q9/Q10. 29 January. Oslo

Hussain, A.S., AAPS Workshop, Pharmaceutical Quality Assessment - A Science and Risk-Based CMC Approach in the $21^{\text {st }}$ Century, Quality by Design $(\mathrm{QbD})$ - Integration of Prior Knowledge and Pharmaceutical Development into CMC Submission and Review

ICH Q-IWG Members, 2010. ICH Q-IWG Implementation of ICH Q8, Q9, Q10: Breakout B Control Strategy. [workshop] November. available at: http://www.ich.org/products/ guidelines/quality/training-programme-for-q8q9q10/ presentations.html (Accessed 03, 2011)

ICH Q-IWG Members, 2010. ICH Q-IWG Implementation of ICH Q8, Q9, Q10: How ICH Q8, Q9, Q10 guidelines are working together throughout the product life cycle. [workshop] October. Washington DC, available at: http://www.ich. org/products/guidelines/quality/training-programme-forq8q9q10/presentations.html (Accessed 03,2011)

ICH Q9 EWG, 2006. ICH. Quality Risk Management ICH Q9 Executive summary for competent authorities and industry. July

Kenett, D., Kenett, R., 2009. Challenges in Global Product Development. Quality by Design Approach in Biopharmaceutical Products. [lecture] 2 April. Bar-Ilan University

Kerridge, J., 2008. Risk Management - Industry experience. 3 April

Korakianiti, E., 2009. EMEA, QWP: Quality Assessors Training "New quality paradigm: Quality by Design" ICH Q8 Q8-910 , October $26-27$

Krause, M., 2007. ICH Q8 Pharmaceutical Development, ICH Q9 Quality Risk Management, ICH Q10 Pharmaceutical Quality System: vision, concept and their potential impact on industry and regulators - will they foster innovation? M. A. Rheinischen Friedrich-Wilhelms-Universität Bonn

Laar, V.T. Back to Basics. (World Pharmaceutical Frontiers) [online] Available at: www.worldpharmaceuticals.net [Accessed February 2011]

Lionberger, R.A., Lee, S.L., Lee, L.M., Raw A., Yu, L.X., 2008. Quality by Design: Concepts for ANDAs. American Association of Pharmaceutical Scientists. [Online] 10 (2), pp. 268- 276 Available at: http://www.springerlink.com (Accessed 10 April 2010).

Lo, S., Venkatesh, K., Foster, G., 2006. Benefits and Challenges of PAT Implementation in Generic Pharmaceutical
Manufacturing. American Pharmaceutical Review, 3, (1), pp. 13-18.

Luigetti, R. The Siena Conference on Product and Process Optimization, 2008. QbD: A Global Implementation Perspective - The EU Perspective, October 6, Siena, Italy

Moelgaard, G. QbD - Quality by design Methods to simplify the Development and production Phases in life science. Available at: http://www.mva.org/media(4384,1033)/ Presentation\%3A_NNE_Pharmaplan.pdf (Accessed 10 May 2011)

Massa, T., 2004. Advisory Committee for Pharmaceutical Sciences Manufacturing Subcommittee. Life Cycle Management for Process and System Control An Industry Proposal. 20 July

Masurkar, S., 2010. ARDL - I: An introduction to ICH. [presentation] 11 July. available at: http://www.authorstream. com/Presentation/bharatrbh-436843-introduction-to-ich/ (Accessed 02, 2011)

Miksinski, P. S., 2009. FDA, What Does Quality By Design Bring To Your Drug Development Program?, November 6

Moreton, C., 2010. Southern California Pharmaceutical Discussion Group. Excipients and Quality by Design. 10 June

Nasr, M.M., 2005. Advisory Committee of Pharmaceutical Science (ACPS). Establishing Drug release/Dissolution Specifications -QbD Approach. 25 October

Nasr, M.M., 2009. Pharmaceutical Science and Clinical Pharmacology Advisory Committee Meeting, Status and Implementation of ICH Q8, Q9, and Q10 Quality Guidelines, August 5, Rockville

Neway, J., 2008. How to Make the Business Case for Quality by Design No time for QbD? How to convince management to make it a priority? Bio Pharm International. [Online] 21 (12) Available at: http://biopharminternational.findpharma.com/ biopharm/Regulatory+Compliance+Articles/How-to-Makethe-Business-Case-for-Quality-byDesig/ArticleStandard/ Article/detail/568935. (Accessed 11 December 2010).

Peterson, J.J., Snee, D. R., McAllister, R.P., Schofield, L.T., Carella, A., 2009. Statistics in pharmaceutical development and manufacturing. [online] Available at: http://biometrics. $\mathrm{com} /$ ?m=2009\&paged=7 [Accessed 11 December 2010]

Pharm Tech, 2007. The Application of Quality by Design to Analytical Methods. [online] Available at: http://pharmtech. findpharma.com/pharmtech/Peer-Reviewed+Research/ The-Application-of-Quality-by-Design-to-Analytical/ ArticleStandard/Article/detail/463580 [27 February 2011]

Pharma QbD, 2009. Why quality-by-design should be on the executive team's agenda. [online] Available at: http:// www.pharmaqbd.com/wp-content/uploads/2011/01/QbD McKinsey.pdf [5 February 2011]

Pharma QbD, 2008. Pharmaceutical Development Case Study: "ACE Tablets". [online] Available at: http://www.pharmaqbd. com/qbd_guidance/ [5 February 2011]

PhRMA CMC Statistics and Stability Expert Teams, 2003. Identification of Out-of Trend Stability Results, A Review of the Potential Regulatory Issue and Various Approaches. (Pharmaceutical Technology) [online] Available at: www. pharmtech.com [Accessed 27 February 2011]

Oiu, Y., Chen, Y., Zhang, G.Z.G., Eds., 2009. Developing Solid Oral Dosage Forms Pharmaceutical Theory and Practice, New York, Academic Press

Saari, H-L., 2004. Risk management in drug development projects. [online] Available at: http://jobfunctions.bnet.com/ abstract.aspx?docid=154472 [Accessed 5 December 2010]

Sabir, A., AAPS, 2010. Life Research Hope, Generics Embracing 
QbD / PAT Globally. Tampa, Florida

Sam, T., 2008. WHO Training Workshop on Pharmaceutical Development with Focus on Pediatric Formulations, Quality by Design. [workshop] May. Mumbai, India

Shah, B.R., 2009. AAPS. Quality by design in Pharmaceutical manufacturing. Chicago. Available at: http://www. aapspharmaceutica.com/inside/discussiongroups/chicago/ imagespdfs/ShahNov2009.pdf (Accessed 5 April 2011)

Smith, C.G.,O'Donnell, J.T., eds., 2006. The Process of New Drug Discovery and Development. 2nd Edition, New York: Informa Healthcare

Snee, D.R., Cini, P., Jason, J., Kamm, J.J., Meyers, C.A., 2008. Quality by design shortening the path to acceptance. (Tunnell Consulting) [online] Available at:http://www. tunnellconsulting.com/library/published-articles/synopsis. php?id=19 [Accessed 11 December 2010]

Somma, R. SommaTech. Using Quality by Design (QbD) in Designing Efficient FDA compliant Pharmaceutical Manufacturing Processes and Facilities. Available at: http:// www.sommatechconsulting.com/site/images/stories/news room/events/using_qbd.pdf (Accessed 10 May 2011)
The European Agency for the Evaluation of Medicinal Products Human Medicines Evaluation Unit, Note for Guidance, 1996/155/CPMP/QWP, 28 January 1998 on development pharmaceutics

Turner, J. R., 2007. New Drug Development-Design, Methodology and Analysis, New Jersey: John Wiley \& Sons

Urkin, E., Magenheim B., 2009. Challenges in Global Product Development 1, The ICH Quality Vision \& Implementation Model Q8, Q9, Q10, March 31, April 1-2, Bar Ilan University, Israel

Wilkinson, N., 2008. QP Symposium. ICH Q10 - Delivering a Modern Effective Pharmaceutical Quality System. April. London

World Health Organization., 2010. Quality by Design. [workshop] 21 to 25 June. Beijing, PR of China

Wyvratt, J., 2009. FDA Advisory Committee on Pharmaceutical Science \& Clinical Pharmacology. ICH Quality IWG Questions \& Answers: Quality by Design Aspects. 5 August

\title{
Анализа и критички осврт на ICH Q8, Q9 и Q10 од аспект на генеричка фармацевтска индустрија
}

\author{
Љуба Каранаков ${ }^{1 *}$, Јасмина Тониќ-Рибарска², Марија Главаш-Додов ${ }^{3}$, \\ Сузана Трајковиќ-Јолевска²
}

${ }^{1}$ Реплек Фарм Ltd, Козле 188, Скопје, Македонија

${ }^{2}$ Институт за применета хемија и фармацевтски анализи, Фармацевтски факултет, Универзитет „Св. Кирил и Методиј“, Скопје

${ }^{3}$ Институт за фармацевтска технологија, Фармацевтски факултет, Универзитет „,Св. Кирил и Методиј“, Cкопје

Клучни зборови: ICH водичи, фармацевтски развој, управување со ризикот за квалитет, фармацевтски систем за квалитет, квалитет преку дизајн, процесна аналитичка технологија

Генеричката индустрија има за цел да произведе сигурни, ефикасни лекови со вграден квалитет, кои ќе ги задоволат барањата на пациентите и ќе бидат конкурентни на пазарот. Во овој труд преку анализа на водичите ICH Q8, Q9 и Q10 и нивна имплементација во Европската регулатива, направена е процена за потребата од имплеметација на квалитет преку дизајн $(\mathrm{QbD})$ и процесна аналитичка технологија (PAT) од страна на генеричка индустрија. Прегледот на водичите укажува на разликите во животниот циклус на генерички лек, водејќ́ до краен заклучок од аспект на генеричка индустрија.

РАТ овозможува статистичка анализа и следење на квалитетот во реално време, како основа за проактивно управување со квалитетот. Со употреба на $\mathrm{QbD} / \mathrm{PAT}$, квалитетот се докажува и подобрува во текот на целиот животен циклус.

Изведен е заклучок дека апликантот треба да ја оптимизира имплементацијата на QbD во согласност со важечките водичи за добра производна пракса, земајќи ги во предвид своите производствени можности. Имплементацијата на $\mathrm{QbD} / \mathrm{PAT}$ е иновативен предизвик за генеричката индустрија. Управувањето со фармацевтски систем за квалитет му овозможува на највисокиот менаџмент да носи вистински одлуки во вистинско време.

Макед. фарм. билт., 57 (1, 2) 85 - 96 (2011) 
Подоброто разбирање на производот и процесите во рамките на дефиниран простор во дизајн води кон полесно докажување на вграден квалитет во текот на животниот циклус на лекот, побрза и полесна регулаторна евалуација, побрза комерцијализација, како и заштеда на постмаркетиншки трошоци и време.

Имплементацијата на QbD/PAT како системски пристап кој користи процена на ризик, како дел од систем за управување со квалитет, претставува корисен предизвик за генеричката индустрија и нуди можности за, технолошко, временско и финансиско унапредување, како и подобрување на квалитетот. 